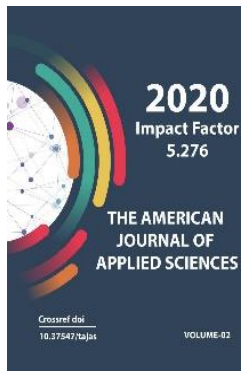

Copyright: Original content from this work may be used under the terms of the creative commons attributes 4.0 licence.

\section{Depth Faults Along The Regmatic Network Of The Chatkalo- Kuramin Region And Their Relationship With Seismicity}

\author{
Madinabonu Zaxritdinovna Fazliddinova \\ Master student, Faculty of Geology and Geographic Information Systems National University \\ of Uzbekistan named after Mirzo Ulugbek, Uzbekistan
}

\begin{abstract}
Akram Bayramovich Goipov
Doctor of Philosophy (PhD) in geological and mineralogical sciences, Associate Professor, Faculty of Geology and Geographic Information Systems National University of Uzbekistan named after Mirzo Ulugbek, Uzbekistan
\end{abstract}

Maftuna Asad qizi Saidova

Head of Cabinet Department of Earth Remote Sensing and Engineering Geology, University of Geological Sciences, Uzbekistan

\title{
ABSTRACT
}

Lineaments were identified using LANDSAT-8 satellite images and digital elevation models obtained from the ASTER GDEM satellite over the Chatkal-Kuramin region. Taking into account the stock materials and a comprehensive analysis of the results of processing remote sensing data, a map of lineaments of a 1:100,000 regmatic network was compiled. Based on the automated visual lineament analysis in the Geomatica $\mathrm{PCl}$ program, lineaments of the regmatic network were obtained, which are located in the focal zones of strong earthquakes.

\section{KEYWORDS}

Space images, ASTER, seismic lineament, faults, magnitude, regmatic network, seismicity.

\section{INTRODUCTION}

The presence of a regmatic network of faults in Central Asia is substantiated in the works of VV Kiselev, VG Korolev [1], OM Borisov [2, 3], D.Kh. Yakubov and others [4], V. S. Burmana [5], L. M. Rassvetaeva and others [6]. It was found that a single network of straight-line faults consists of six components, and the angular intervals between the rays vary from 22 to $23^{\circ}$. However, in space, their density and completeness of manifestation are different and most often in a particular region a 4 or 6 - component network is more pronounced. The stability of the strike allowed V.S.Burtman to call it stationary [5].

In the Chatkalo-Kuramin mountains, for the first time, a regmatic lineament-rupture network based on the interpretation of aerial photographic materials was described by A.K. Glukh [7], who identified six main components $\left(0^{\circ}, 20^{\circ}, 60^{\circ}, 90^{\circ}, 310^{\circ}, 340^{\circ}\right)$

In the analysis and interpretation of space images, decoding of linear structures or 
lineament is used. For the first time this term was used in 1904 by the American geomorphologist Hobbs [8]. According to which, at present, lineament is understood as any rectilinear change in the relief of the earth's surface, landscape and geographical objects. Ya.G. Kats et al. Noted that in accordance with the initial materials of interpretation, lineaments in the seismic field seismic lineaments - can be distinguished [9].

Deciphering linear structures in seismic zoning is used in a number of areas of earth science. Based on this, the lineaments were deciphered using stock materials and seismological analysis of the studied territories was carried out.

Seismic lineament are understood as a strip quasi-linear arrangement of sources of modern and ancient earthquakes of various magnitudes and depths [10, 11].

\section{RESEARCH METHODOLOGY}

The object of research is a mountain structure, united by the name of the Chatkalo-Kuramin region and located in the Middle Tien Shan.
In the morphological appearance of the Chatkal-Kuramin region, the features of connections between the relief and structures are clearly expressed. The ubiquitous nature of the manifestation of the latest tectonic movements determines the features of the modern relief.

This work was carried out on the basis of the use of automated lineament analysis in the Geomatica $\mathrm{PCl}$ program, which makes it possible to obtain linear structures.

In order to identify lineaments, an automated interpretation of the data of digital elevation models obtained from the ASTER GDEM satellite was carried out and, taking into account the stock materials, maps of lineaments of 1: 100,000 scale were compiled (Fig. 1). 


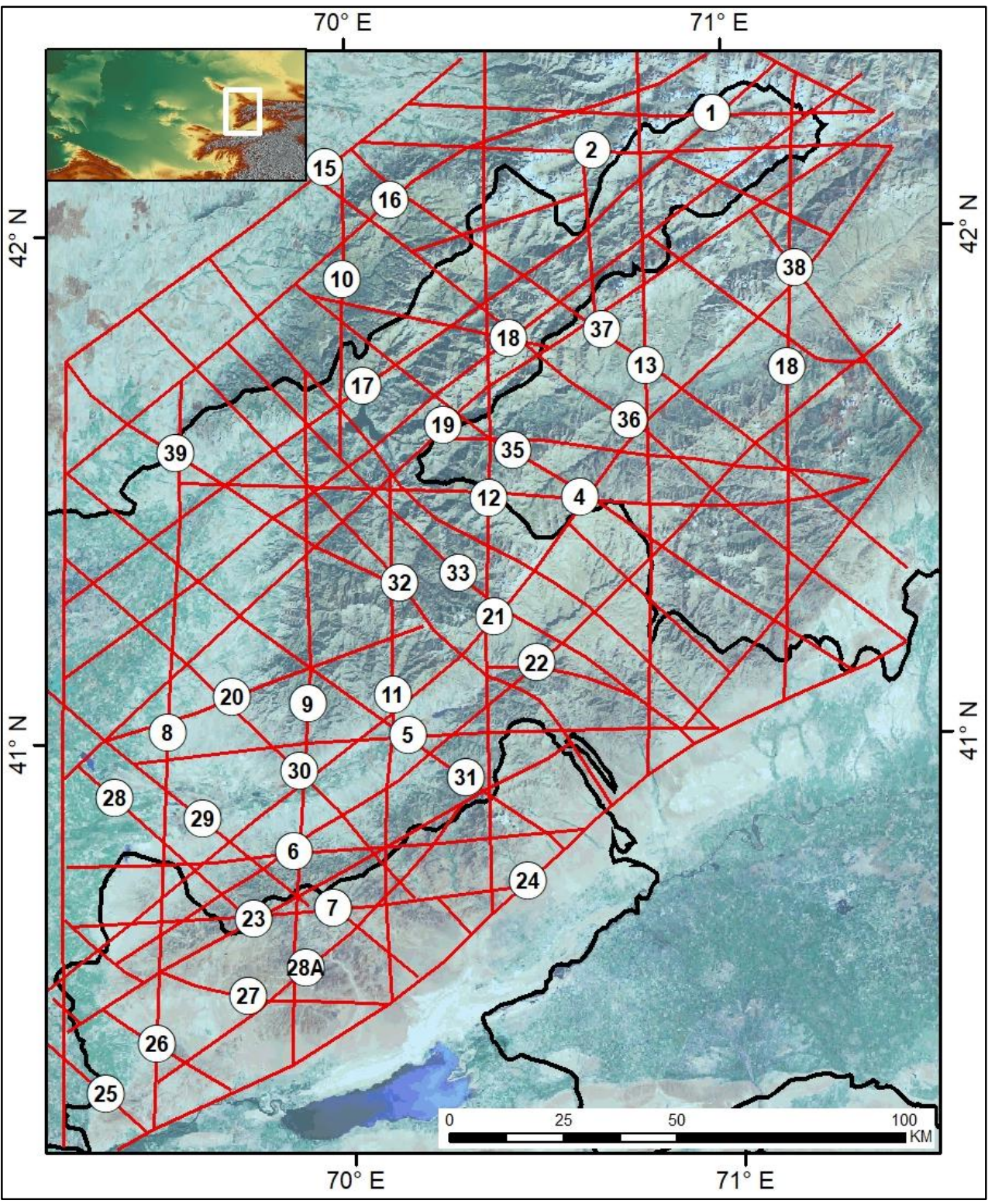

Figure: 1. Maps of the lineaments of the Chatkal-Kuramin region (using materials by V.N. Tkachev).

The Chatkal-Kuramin region is an area of block tectonics with the expression in the relief of the newest and updated faults inherited from the ancient and periodically renewed at various stages of the development of the region's crust. The region is characterized by spatial continuity in the development of young structural forms from older ones. Almost all faults in the region are inherited and renewed $[12,13]$.
According to V.A. Arapov, geological and geophysical material and interpretation of satellite images have established a regmatic network of large deep faults in the ChatkalKuramin region. Orthogonal and diagonal fault networks have been identified, which are controlled on the surface by corresponding fault systems. According to the strike azimuths, they are subdivided into latitudinal, meridional (orthogonal), northwest and northeast (diagonal). The latitudinal deep 
faults include Okurdavan, Bashtavak, Nizhnechatkalsky, Tekesh-Barkraksky and Kassansai. On the surface, they are accompanied by the Barkrak, Kassan and Akhangaran-Bashtavak fault systems. Ashabinsky, Dukent-Gushsaysky, MaygashkanAkchinsky, Kugala-Charkasarsky, Ugamsky are classified as meridional deep faults. On the surface, they are expressed by the UgamGushsai system of faults [14].

Northwestern directions are represented by the Effusive, Umbetta, Almalyk, Akdzhilak, Shavaz-Kandyrsay, Karabau-Naugarzansky, Kumbelsky, Kenkol, Arashan, Ihnach and Koksarek deep faults, accompanied on the surface by the Mirumbzorakbat, KarabauNaugarzansky, Koksarek and Koksarek deep faults, accompanied by the Mirumbzorakbat, Ikhbashyrek-Kandyr-batsky, Almashaly-UgalyKarek systems faults. Angrenskiy, TashkentPskemskiy, Beshtor-Tundukskiy, NurekataSandalashskiy, Chilten-Chatkalskiy, AlmalykNaugarzanskiy, Akhangaranskiy, Lashkerekskiy and Severo-Ferganskiy are assigned to the northeastern deep faults. On the surface, they are expressed by the North Karzhantau, Tashkent-Pskem and ChatkalAngren fault systems [11-13].

Latitudinal faults appear on the surface both in the form of large, well-developed tectonic zones (Bashtavak, Tekeli-Barirak, etc.), and in the form of zones that control the placement of magmatic bodies.

The meridional faults were first identified according to aeromagnetic survey data (Kotlyarevsky et al., 1968) and were further confirmed by detailed geological studies. Large structures of this direction are noted both in the western (Dukent-Gushsai) and eastern (Ashabinsky, Kugala-Charkassarsky) parts of the Kuramin zone. Some of them are represented on the surface by a series of small subparallel faults (Ugam-Gushsai system) or large elaborated zones (Ugam fault), others are weakly manifested.

Northwestern faults are most typical for the Kuraminskaya part of the region and especially for the boundary strip separating the Chatkal and Kuraminskaya zones and represented by the Ugam-Kumbelskaya system of deep faults, which determines the position of the Tereklinskaya depression. Disjunctiva of the indicated direction are represented by large and well-developed fault zones (Kumbelsky, Arashansky), or a series of close sub-parallel small faults along the Koksarek, Ihnachsky, Kenkol deep faults [1-3, 13].

In the Chatkal zone, northwestern faults serve as transverse seams that divide large northeastern consedimentary structures into blocks of various levels with maximum subsidence in the southwestern direction.

It has been established that tectonic nodes are the place where the redistribution of elastic energy and deformation of the earth's crust occurs. The structural features of the nodes are: mosaic (fragmentation) of the relief, variegation (both in composition and age) of rocks, a large number of linear relief forms [15].

The resulting lineament maps are compared with the catalogs of earthquakes from 11.11.1920 to 11.11.2020, obtained from the site https://earthquake.usgs.gov/. The mapped deep fault zone, the intersection nodes of multidirectional faults and structures in many cases control the position of the earthquake catalog (Fig. 2). 


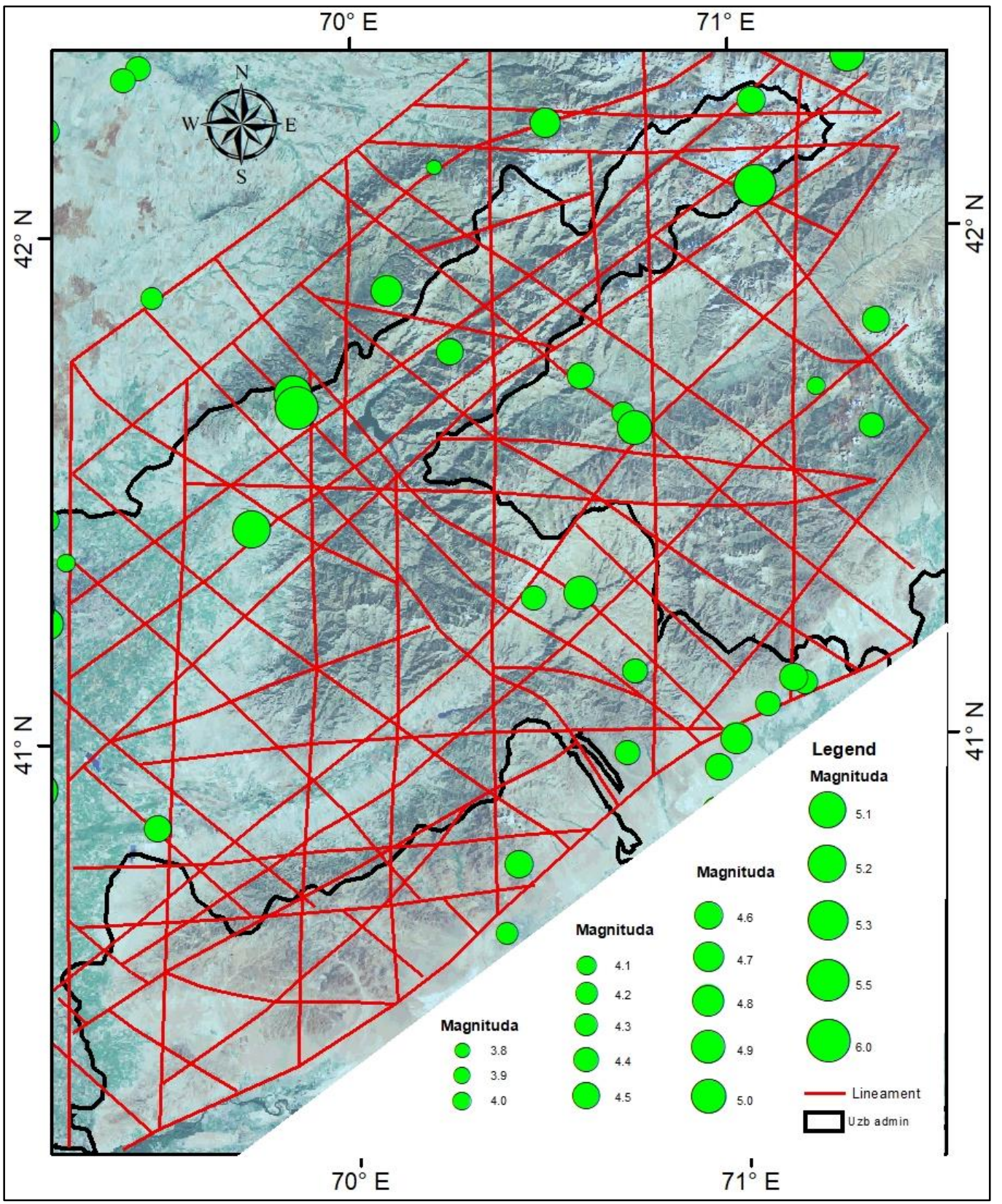

Figure: 2. The main large lineaments of the earth's crust with a catalog of strong earthquakes in the Chatkalo-Kuramin region (based on materials by V.I. Makarov, L.I.Solovyeva, 1976; O.M.Borisova, A.K. Glukha, 1982; A.K. Glukha, 1975; V.N. Tkacheva, 2004).

The mountain structures of the ChatkalKuramin region are tectonically part of the alpine epiplatform orogen. The modern appearance is determined by the Neogene and modern movements with the formation of systems of uplifts and depressions, modern river valleys of northeastern striking. 
In the pre-Mesozoic tectonic plan, the main place belongs to the structures of Hercynian tectogenesis. Moreover, within the Chatkal geosynclinal subzone, linear folds are mainly inherited by modern structures, while within the Fergana-Kuraminsky median massif (Karzhantau-Kuraminskie mountains), blockfolded brachyclines of sub-latitudinal strike and volcanotectonic structures prevail in relation to them. , modern structures are newly formed [14].

The tectonic structure of the area is determined by a relatively complexly dislocated Paleozoic basement, the formation of which took place during the Varissian orogeny and ended in the era of Alpine folding.

According to the distribution of earthquakes for 1960-2017 within the active structures of the Northern Fergana, the Kuramin and Chatkal uplifts, areas of earthquake concentration are identified, which reflect the processes of dynamic segmentation and dynamic sectorization of active structures [16].

As a result of research work, a map of the density field of tectonic disturbance in an isolinear form along different directions of the fault grid and a map of the total field (taking into account faults of all directions and faults) were compiled. The differences in the density of the faults reflected on the maps made it possible to record in detail the block structure of the earth's crust of the Chatkal-Kuramin region, to reveal faults (hidden, through type, block-limiting, block-dividing and most active blocks) and to identify seismologically important (predicted) directions of the fault grid and intervals (areas) density fields of tectonic disturbance (Fig. 3).

It was noted (R.D. Dzhenchuraeva, 2001) that deep faults along the regmatic network are currently recorded by shallow earthquakes and increased heat flows [17].

The origin of deep faults developed along the regmatic network is quite well explained by the hypothesis of changes in the axes of rotation of the Earth when it moves along with the Sun in a galactic orbit. The regmatic network originated 3150 million years ago. One rotation in the galactic orbit takes 1200 million years. Every 150 and 300 million years the rotation axes coincide, which is marked by the main epochs of folding $[18,19]$.

V.A. Arapov suggests that deep faults along the regmatic network in the Chatkal-Kuramin region were laid in the pre-Upper Riphean stage of its development [14]. 


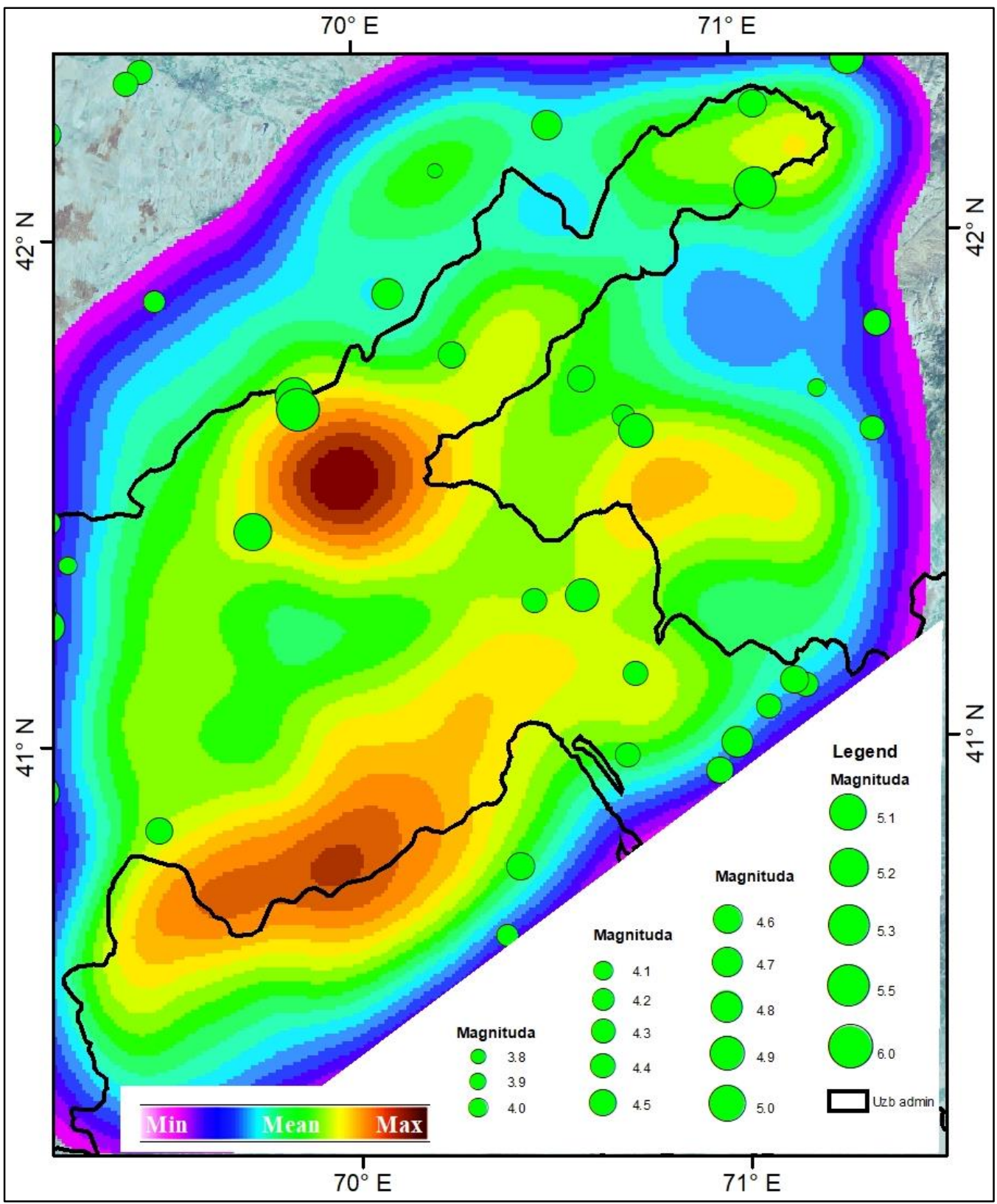

Figure: 3. Map of the density field of tectonic disturbance.

It has been established that intense deformations occur in seismic areas due to global and regional stress fields occurring in fault zones [20], since an earthquake occurs in fault zones or a fault is formed in focal zones of earthquakes. To construct the mechanism of the source of earthquakes, it is necessary to apply radar interferometry through the processing of materials from radar satellite images.

For the territory of Central Asia, it was established that although most of the regional deep faults spatially coincide with the lineaments [3-4], in our opinion, in the territory of the Chatkal-Kuramin region 
(Middle Tien Shan), these faults control seismically active zones and are very relevant.

\section{CONCLUSION}

On the territory of the Chatkal-Kuramin region, methodological methods of using tectonic fracturing as one of the criteria for assessing seismic hazard were previously developed [21].

Fig. 3 that the catalog of earthquakes on the map of the tectonic disturbance density field is located within the boundaries of the fracture zone of the average value.

The field of elastic stresses and strains is an important characteristic of the dynamics of the earth's crust and its seismicity [22]. The study of seismicity and seismic dislocation of the Chatkal-Kuramin region using the results of decoding the materials of remote sensing of the Earth, made it possible to identify the main seismic control lineaments, which are located in the multidirectional fault zone in the source zones of strong earthquakes.

\section{REFERENCES}

1. Kiselev V.V., Korolev V.G. Besh-Tashterek right strike-slip fault and strike-slip tectonics in the western part of the northern Tien Shan // Tectonics of the western regions of the Northern Tien Shan. - Frunze: Ilim, 1964.

2. Borisov O.M., Glukh A.K. Ring structures and lineaments of Central Asia. - T .: Fan, 1982 .- $124 \mathrm{p}$.

3. Borisov OM Fault tectonics of Central Asia // Metallogenic problems of Central Asia. - T., 1982 .-- S. 37-52.

4. Yakubov D.Kh., Akhmedzhanov M.A., Borisov O.M. Regional faults of the
Middle and South Tien Shan. - T .: Fan, 1976 .-- S. 95-96.

5. Burtman V.S. Stationary network of continental faults and mobilism // Geotectonics. - 1978. - No. 3. - S. 26-37.

6. Problems of the global correlation of geological phenomena // Proceedings of the GIN AN SSSR / Ed. A.V. Peive. - $M$.: Nauka, 1980. - Issue. 340 .-- 218 p.

7. Glukh A.K. Experience in interpreting space images for compiling a small-scale cosmophotogeological map of the Chatkal-Kuramin mountains (Middle Tien Shan) // Earth Research from Space. 1980. - No. 4.

8. Hobbs W.H. Lineaments of the Atlantic border region // Geological Society. American Bulletin. 1904. - Vol. 15. - P. 483506.

9. Katz Ya.G., Poletaev A.I., Rumyantseva E.F. Fundamentals of Lineament Tectonics. - M .: Nedra, 1986 .-- 134 p.

10. Yarmukhamedov A.R. Contemporary geodynamic activity of the Earth's crust in Central Asia and its relationship with seismicity. - T .: University, 1995 -- $130 \mathrm{p}$.

11. Yarmukhamedov A.R. Late Pleistocene (young and modern) tectonic activity of the earth's crust in the Western Tien Shan and its relationship with seismicity: Author's abstract. diss. ... doct. geol.-min. sciences. - T., 1991.

12. Tkachev V.N. Matsokina-Voronich TM, et al. Legend of the map of patterns of distribution and forecasts of minerals at a scale of 1:50 000 on the example of the Chatkal mining region // Uzbek Geological Journal. - 1996. - No. 4. - S. 25-87.

13. Tkachev V.N., Islamov F.I., Rafikov Ya.M. and others. Working supporting legend of the Paleozoic formations of the state map at a scale of 1:50 000 of the Kuraminsky mining region // Uzbek Geological Journal. - 1998. - No. 3.

14. Arapov V.A. Volcanism and tectonics of the Chatkal-Kuramin region. - $\mathrm{T}$.: Fan, 1983 -- 255 p. 
15. Yarmukhamedov A.R., Denisov R.I., Ergashev Sh.E. et al. On the spatial relationship of mineral deposits with faults and ring structures (on the example of the Chatkalo-Kuramin mountains) // Tr. scientific-practical conf. "Problems of ore deposits and increasing the efficiency of geological exploration". T., 2003 .-- S. 81-83.

16. Omuralieva A., Omuraliev M.O. Dynamics of seismicity in the northern part of the Fergana depression, the Kuramin and Chatkal uplifts of the Tien Shan // Bulletin of the Institute of Seismology of the National Academy of Sciences of the Kyrgyz Republic. - 2018. - No. 2 (12). - S. 5362.

17. Dzhenchuraeva R.D. Transregional deep structures of the Tien Shan and their role in the formation of large deposits // Geology and Geophysics. - 2001. - No. 10. S. 1476-1483.

18. Khain V.E. General geotectonics. - $M$.: Nedra, 1973 .- $512 \mathrm{p}$.

19. Khain V.E., Poletaev A.I. Rotational tectonics of the Earth // Science in Russia. - 2007. - No. 6. - S. 14-21.

20. Bondur V.G., Zverev A.T. Earthquake prediction method based on lineament analysis of space images // Dokl. Academy of Sciences. 2005. - T. 402. - No. 1. - S. 98105.

21. Shishkin E.I. Features of the latest development of the Chatkal-Kuramin region in connection with seismicity: Author's abstract. diss. ... Cand. geol.-min. sciences. - M., 1990.

22. Ulomov V.I. On the role of horizontal tectonic movements in seismogeodynamics and seismic hazard prediction // Physics of the Earth. - 2004. No. 9. - S. 14-30. 